\title{
Electrolytic Reduction of Titanium Dioxide in Molten $\mathrm{LiCl}-\mathrm{Li}_{2} \mathrm{O}$
}

\author{
Meng Shi ${ }^{1}$, Bin Liu ${ }^{2}$, Shelly $\mathrm{Li}^{3}{ }^{3}$ and Haiyan Zhao ${ }^{1, *}$ \\ 1 Department of Chemical \& Biological Engineering, University of Idaho (Idaho Falls), 995 MK Simpson Blvd., \\ Idaho Falls, ID 83401, USA; shi7608@vandals.uidaho.edu \\ 2 Department of Chemical Engineering, Kansas State University, Manhattan, KS 66506, USA; binliu@k-state.edu \\ 3 Idaho National Laboratory, Idaho Falls, ID 83401, USA; sxiaoweili@gmail.com \\ * Correspondence: haiyanz@uidaho.edu; Tel.: +1-208-533-8123
}

check for

updates

Citation: Shi, M.; Liu, B.; Li, S.; Zhao H. Electrolytic Reduction of Titanium Dioxide in Molten $\mathrm{LiCl}-\mathrm{Li}_{2} \mathrm{O}$. Electrochem 2021, 2, 224-235. https:// doi.org/10.3390/electrochem2020016

Academic Editor: Masato Sone

Received: 8 March 2021

Accepted: 23 April 2021

Published: 27 April 2021

Publisher's Note: MDPI stays neutral with regard to jurisdictional claims in published maps and institutional affiliations.

Copyright: (c) 2021 by the authors. Licensee MDPI, Basel, Switzerland. This article is an open access article distributed under the terms and conditions of the Creative Commons Attribution (CC BY) license (https:// creativecommons.org/licenses/by/ $4.0 /)$.

\begin{abstract}
The electrolytic reduction of $\mathrm{TiO}_{2}$ in $\mathrm{LiCl}-\mathrm{Li}_{2} \mathrm{O}(1 \mathrm{wt} . \%)$ at $650{ }^{\circ} \mathrm{C}$ was investigated under a series of cathodic reduction potentials and applied charges to provide a mechanistic understanding of the electrochemical characteristics of the system. The optimal cathodic reduction potential was determined as being $-0.3 \mathrm{~V}$ vs. $\mathrm{Li} / \mathrm{Li}^{+} . \mathrm{Li}_{2} \mathrm{TiO}_{3}$ and $\mathrm{LiTiO}_{2}$ were structurally identified as intermediate and partial reduction products of the $\mathrm{TiO}_{2}$ electrolytic reduction. The reduction of $\mathrm{LiTiO}_{2}$ was extremely slow and reversible due to its high stability and the detrimental effect of $\mathrm{Li}_{2} \mathrm{O}$ accumulation within the solid particles. The most reduced product obtained in this study was $\mathrm{LiTiO}_{2}$, which was achieved when using $150 \%$ of the theoretical charge under the optimal reduction potential. The highest reduction extent obtained in this study was $25 \%$. Based on theoretical DFT modeling, a detailed multistep reduction mechanism and scheme were proposed for $\mathrm{TiO}_{2}$ electrolytic reduction in $\mathrm{LiCl}-\mathrm{Li}_{2} \mathrm{O}(1 \mathrm{wt} . \%)$ at $650{ }^{\circ} \mathrm{C}$.
\end{abstract}

Keywords: cathodic reduction; titanium dioxide; lithiothermic reduction; reduction mechanism; lithium titanate

\section{Introduction}

Titanates and titanium metal are valuable for batteries, coatings, and structural material applications [1-4]. Electrolytic reduction is a promising way for Ti metal and intermediates production directly from solid titanium dioxide through molten salt electrolysis. It has attracted extensive research effort that involves using various salt systems under various conditions with different setups [5-9]. The Fray-Farthing-Chen (FFC) Cambridge and calciothermic Ono-Suzuki (OS) processes are the two most well-studied processes utilizing $\mathrm{CaCl}_{2}$ (melting point $772{ }^{\circ} \mathrm{C}$ ) as electrolytes for electrolytic reduction between 850 and $950^{\circ} \mathrm{C}$. As an alternative electrolyte, $\mathrm{LiCl}$ can significantly decrease the reduction temperature to $650{ }^{\circ} \mathrm{C}$ for the electrolytic reduction of metal oxides due to its lower melting point [10-12]. The FFC process presumes that $\mathrm{TiO}_{2}$ is reduced directly in $\mathrm{CaCl}_{2}$ via electrons through multiple titanate intermediates, including $\mathrm{CaTiO}_{3}$ and $\mathrm{CaTi}_{2} \mathrm{O}_{4}$, as well as titanium suboxides $\left(\mathrm{TiO}_{\mathrm{x}}, \mathrm{x}<2\right)$ [13-16]. Through the OS process, $\mathrm{TiO}_{2}$ is reduced using in-situ-generated calcium metal from the $\mathrm{CaCl}_{2}$ electrolyte at an overpotential when the applied potential is higher than the electrolyte decomposition potential $[7-9,17,18]$. Similarly, the reduction of $\mathrm{TiO}_{2}$ in $\mathrm{LiCl}$ leads to the formation of lithium titanates, including $\mathrm{LiTiO}_{2}$ and $\mathrm{Li}_{2} \mathrm{TiO}_{4}$ when the reduction potential is lower than the $\mathrm{LiCl}$ decomposition potential, that is, an underpotential. The complete reduction of $\mathrm{TiO}_{2}$ to $\mathrm{Ti}$ is obtained at high cell potentials $[10,19,20]$. Regarding the electrolytic reduction of $\mathrm{TiO}_{2}$ in molten $\mathrm{LiCl}-\mathrm{Li}_{2} \mathrm{O}$, the oxides $\mathrm{Li}_{2} \mathrm{TiO}_{4}, \mathrm{LiTiO}_{2}$, and suboxides have been identified using XRD and TEM under various temperatures and potentials (Table 1) [10,19-21]. $\mathrm{Li}_{2} \mathrm{TiO}_{3}$ was reported based on cyclic voltammetry $(\mathrm{CV})$ results. 
Table 1. Electrolytic reduction products for $\mathrm{TiO}_{2}$ in $\mathrm{LiCl}$ salts.

\begin{tabular}{|c|c|c|c|c|}
\hline Reference & Temperature & Reduction Conditions & Products & Characterization \\
\hline [19] & $700^{\circ} \mathrm{C}$ & $\begin{array}{c}\mathrm{TiO}_{2} \text { pellets, cell potentials } 1.8 \mathrm{~V} \\
\text { and } 3.2 \mathrm{~V}\end{array}$ & $\mathrm{Li}_{2} \mathrm{TiO}_{4}, \mathrm{LiTiO}_{2}$ & ICP, XRD, and TEM \\
\hline [20] & $650{ }^{\circ} \mathrm{C}$ & $\begin{array}{c}\mathrm{TiO}_{2} \text { powder, constant current at } \\
1.2 \mathrm{~A} \text {, cell potential } 2.7 \mathrm{~V}\end{array}$ & $\mathrm{Li}_{2} \mathrm{TiO}_{4}, \mathrm{LiTiO}_{2}, \mathrm{Ti}$ & XRD and SEM \\
\hline [10] & $650^{\circ} \mathrm{C}$ & $\mathrm{TiO}_{2}$ powder, cell potential $3.0 \mathrm{~V}$ & $\mathrm{LiTiO}_{2}, \mathrm{TiO}, \mathrm{Ti}_{2} \mathrm{O}, \mathrm{Ti}$ & XRD and SEM \\
\hline [21] & $850^{\circ} \mathrm{C}$ & $\begin{array}{c}\text { Thin } \mathrm{TiO}_{2} \text { film, } \\
0 \text { to }-2.0 \mathrm{~V} \text { vs. } \mathrm{Ni} / \mathrm{NiO}\end{array}$ & $\begin{array}{c}\mathrm{Li}_{2} \mathrm{TiO}_{3}, \mathrm{TiO}, \mathrm{Ti}_{3} \mathrm{O}_{5} \\
\mathrm{Ti}_{2} \mathrm{O}_{3}, \mathrm{Ti}\end{array}$ & $\mathrm{CV}$ \\
\hline
\end{tabular}

However, the $\mathrm{TiO}_{2}$ reduction mechanism in $\mathrm{LiCl}$ is not as well understood as in $\mathrm{CaCl}_{2}$. The reduction pathways and mechanism of $\mathrm{TiO}_{2}$ in $\mathrm{LiCl}$ have mostly been studied using two-electrode electrochemical cells. It is unclear whether the underpotential (lower than the electrolyte decomposition potential) or overpotential electrolytic reduction was employed under these conditions $[10,22,23]$. To elucidate the $\mathrm{TiO}_{2}$ electrolytic reduction mechanism in $\mathrm{LiCl}$, this work systematically investigated the electrolytic reduction of $\mathrm{TiO}_{2}$ in $\mathrm{LiCl}-$ $\mathrm{Li}_{2} \mathrm{O}(1 \mathrm{wt} . \%)$ at $650{ }^{\circ} \mathrm{C}$ using a three-electrode electrolysis cell by directly controlling the cathodic reduction potential under a series of applied charges. Reduction intermediates and products were analyzed and quantified using X-ray diffraction (XRD) with Rietveld refinement analysis. The $\mathrm{CV}$ and chronoamperometry techniques, combined with density functional theory (DFT) calculations, were employed to obtain a detailed understanding of the $\mathrm{TiO}_{2}$ reduction characteristics and mechanisms in the $\mathrm{LiCl}-\mathrm{Li}_{2} \mathrm{O}$ system.

\section{Materials and Methods}

A molten salt mixture, namely, $\mathrm{LiCl}-\mathrm{Li}_{2} \mathrm{O}(1 \mathrm{wt} . \%)$, for $\mathrm{TiO}_{2}$ electrolytic reduction was made of ultra-high-grade lithium chloride ( $\mathrm{LiCl}, 99.995 \%$ metals basis, ultra-dry, Alfa Aesar, Tewksbury, MA, USA) and lithium oxide $\left(\mathrm{Li}_{2} \mathrm{O}, 99.5 \%\right.$, Alfa Aesar), which was used as received. Titanium dioxide powders (Rutile $\mathrm{TiO}_{2}, 99.995 \%$ metals basis, Alfa Aesar) were pelletized, grounded, and sieved between mesh 60 and 20 (particle sizes $0.25 \sim 0.85$ $\mathrm{mm}$ ). A total of $2.0 \mathrm{~g}$ of $\mathrm{TiO}_{2}$ pellets were loaded in a basket for each $\mathrm{TiO}_{2}$ reduction run immersed in a $150 \mathrm{~g}$ electrolyte salt bath at $650^{\circ} \mathrm{C}$.

A three-electrode electrochemical cell located in an argon glovebox (MBraun, Labmaster 200G, Stratham, NH, USA) with controlled moisture and oxygen levels ( $<1 \mathrm{ppm})$ was used for the electrochemical measurement and $\mathrm{TiO}_{2}$ electrolytic reductions. The threeelectrode electrochemical cell was composed of a working electrode, a $\mathrm{Ni} / \mathrm{NiO}$ reference electrode, and a glassy carbon crucible, which was also used as the counter electrode (HTW GAZ30). VersaSTAT 4 Potentiostat (Princeton Applied Research, Oak Ridge, TN, USA), which interfaced with the glovebox, was employed for the electrochemistry measurement and electrolysis up to 2 amps using VersaStudio for controlling the parameters and for data acquisition. A Kerrlab electric furnace (Auto Electro Melt Maxi, Orange, CA, USA) was used to keep the electrolyte salt bath at $650{ }^{\circ} \mathrm{C}$. This three-electrode electrochemical cell setup has shown high efficiency and reliability in a previous study for $\mathrm{NiO}$ electrolytic reduction [24].

Cyclic voltammetry (CV) was measured in the $\mathrm{LiCl}-\mathrm{Li}_{2} \mathrm{O}(1 \mathrm{wt} . \%)$ salts at $650{ }^{\circ} \mathrm{C}$ to determine the Li deposition potential $\left(E_{\mathrm{Li} / \mathrm{Li}^{+}}\right)$at a scan rate of $20 \mathrm{mV} \mathrm{s}^{-1}$ using a $\mathrm{Ni} / \mathrm{NiO}$ reference electrode and a $0.64 \mathrm{~mm}$ diameter stainless steel wire as the working electrode. A cathode basket assembly described in a previous work was used for the $\mathrm{TiO}_{2}$ electrolytic reductions [24]. Briefly, the cathode basket assembly included a $1.59 \mathrm{~mm}$ diameter stainless steel rod as an electron collector and a stainless-steel cathode basket (height: $2.5 \mathrm{~cm}$, diameter: $1 \mathrm{~cm}$ ) made of double layers of 100 mesh stainless steel wire cloth, and the $\mathrm{TiO}_{2}$ pellets were loaded and packed around the electron collector. The whole electrode assembly was soaked in the molten salt for $1 \sim 1.5 \mathrm{~h}$ before the electrolytic reduction started. Various cathodic reduction potentials, including $-0.2 \mathrm{~V},-0.3 \mathrm{~V}$, and $-0.4 \mathrm{Vvs} . \mathrm{Li} / \mathrm{Li}^{+}$were 
applied on $\mathrm{TiO}_{2}$, respectively, using $80 \%$ of the theoretical charge (i.e., the theoretical charge for the complete reduction of $\mathrm{TiO}_{2}$ to $\mathrm{Ti}$ ). The constant reduction potential was applied at an interval mode (the cell spent $8 \mathrm{~min}$ on and $2 \mathrm{~min}$ off) to minimize the excessive lithium metal generated on the working electrode. Higher theoretical charges, namely $130 \%$ and $150 \%$, were also investigated for the $\mathrm{TiO}_{2}$ reduction at the optimal potential, which was determined as being $-0.3 \mathrm{~V} \mathrm{vs}$. $\mathrm{Li} / \mathrm{Li}^{+}$in this study for further investigation. After the $\mathrm{TiO}_{2}$ reductions, the electrode bundles were lifted out of the molten salt and cooled down to room temperature for further treatment and product analysis. To determine the starting composition for the electrolytic reduction, a soaking test was performed by immersing the $\mathrm{TiO}_{2}$ in the $\mathrm{LiCl}-\mathrm{Li}_{2} \mathrm{O}(1 \mathrm{wt} . \%)$ salt at $650{ }^{\circ} \mathrm{C}$ for $5 \mathrm{~h}$ without electrolysis.

The cooled cathode basket assemblies were transferred out of the glovebox and rinsed with nanopure water to remove the extra $\mathrm{LiCl}-\mathrm{Li}_{2} \mathrm{O}$ salts. Then, the samples were retrieved out of the basket and rinsed in acetone for a quick dry. After that, the samples were kept vacuum dried at room temperature overnight. The completely dried samples were ground into fine powders using a pestle and mortar for the X-ray diffraction analysis (Rigaku SmartLab XRD, Wilmington, MA, USA, $\mathrm{Cu} \mathrm{K} \alpha$ radiation at $40 \mathrm{kV}$ and $30 \mathrm{~mA}$ ). The

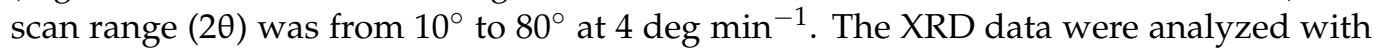
Rietveld refinement using WPPF (whole powder pattern fitting) within PDXL 2 (Rigaku) for quantitative compositional analysis.

In this study, reduction intermediates, including $\mathrm{Li}_{2} \mathrm{TiO}_{3}$ and $\mathrm{LiTiO}_{2}$, were identified and quantified, but $\mathrm{LiTiO}_{2}$ was the only partial reduction product for $\mathrm{TiO}_{2}$. Theoretically, the charge transfer for the reduction of $\mathrm{TiO}_{2}$ to $\mathrm{LiTiO}_{2}$ is 1 , while the charge transfer for the reduction of $\mathrm{TiO}_{2}$ to $\mathrm{Ti}$ is 4 . The reduction extent of $\mathrm{TiO}_{2}$ is defined as given in Equation (1):

$$
\text { Reduction extent }=\frac{\frac{1}{4} \times m_{\mathrm{LiTiO}_{2}}}{m_{\mathrm{TiO}_{2}}+m_{\mathrm{Li}_{2} \mathrm{TiO}_{3}}+m_{\mathrm{LiTiO}_{2}}} \times 100 \%
$$

The total applied charge is represented as a percentage of the theoretical charge, which for the complete reduction of $\mathrm{TiO}_{2}$ to Ti metal is given as Equation (2):

$$
\text { Theoretical charge }=4 m_{\mathrm{TiO}_{2}} F
$$

where $m$ is the number of moles of $\mathrm{TiO}_{2}$, and $F$ is the Faraday constant $\left(96,485 \mathrm{C} \mathrm{mol}^{-1}\right)$.

The Cottrell equation was employed to estimate the oxygen ion diffusion coefficients $(D)$ during the $\mathrm{TiO}_{2}$ electrolytic reduction using the chronoamperometry technique. The oxygen ion diffusion coefficients were calculated based on the I $(t)$ data fit using Equation (3):

$$
I(t)=\frac{n F A D^{1 / 2} C_{0}}{\pi^{1 / 2}} \frac{1}{t^{1 / 2}}
$$

where $I$ is the decay current during the cell-on interval, $n$ is the number of electrons transferred $(n=2), A$ is the surface area of the working electrode, $C_{0}$ is the initial concentration of oxygen ions, and $t$ is the time in seconds.

\section{Density Function Theory Modeling}

Density function theory (DFT) modeling provides theoretical understanding that can be used to determine the $\mathrm{TiO}_{2}$ reduction pathway and mechanism. Vienna Ab Initio Simulation Package (VASP) (Vienna, Austria) was used for the DFT calculation [25]. The Gibbs free energy of formation for titanate intermediates, such as $\mathrm{Li}_{2} \mathrm{TiO}_{3}$ and $\mathrm{LiTiO}_{2}$, were calculated. The calculations of the total energies and structural relaxations were carried out using the projector augmented wave (PAW) method to model the core electrons (see the Supplementary Materials) [26]. The Helmholtz free energy, $F(V, T)$, which is a function of both crystal volume $(V)$ and temperature $(T)$, can be expressed using Equation (4):

$$
F(T, V)=E(V)+F_{v i b}(V, T)+F_{e l}(V, T)
$$


where $E(V)$ is the total energy. $F_{v i b}(V, T)$ and $F_{e l}(V, T)$ represent the vibrational and thermal electronic contributions to the free energy, respectively. The $E(V)$ of a given crystal can be described using the equation of state (EOS), and its values at different volumes were directly obtained from periodic DFT calculations. Here, the fourth-order Birch-Murnaghan (BM4) EOS, as expressed by Equation (5), was used:

$$
E(V)=a+b V^{-2 / 3}+c V^{-4 / 3}+d V^{-2}
$$

\section{Results and Discussion}

\subsection{Soaking Test for $\mathrm{TiO}_{2}$}

Soaking is a routine step for the electrolytic reduction of metal oxides and spent oxide fuels, which allows time for the system to reach stability and for salts to diffuse into the metal oxides matrix before the lithium metal is formed $[11,27,28]$. The soaked $\mathrm{TiO}_{2} \mathrm{sample}$ in $\mathrm{LiCl}-\mathrm{Li}_{2} \mathrm{O}(1 \mathrm{wt} . \%)$ at $650{ }^{\circ} \mathrm{C}$ without electrolysis consisted of three phases, namely, 60.8 wt. $\%$ of $\mathrm{TiO}_{2}, 38$ wt. $\%$ of $\mathrm{Li}_{2} \mathrm{TiO}_{3}$, and $1.2 \mathrm{wt} . \%$ of $\mathrm{Li}_{0.54} \mathrm{Ti}_{2.86} \mathrm{O}_{6}$, based on the XRD analysis (Figure 1). The $\mathrm{Li}_{2} \mathrm{TiO}_{3}$ must be formed chemically via the insertion of $\mathrm{Li}_{2} \mathrm{O}$ into $\mathrm{TiO}_{2}$ on the surface of $\mathrm{TiO}_{2}$ particles through Equation (6), which is analogous to the formation of perovskite $\mathrm{CaTiO}_{3}$ during the $\mathrm{TiO}_{2}$ reduction in calcium salt melt systems [13-15,23]. However, the formation of $\mathrm{Li}_{2} \mathrm{TiO}_{3}$ is spontaneous in $\mathrm{LiCl}-\mathrm{Li}_{2} \mathrm{O}(1 \mathrm{wt} . \%)$ at $650{ }^{\circ} \mathrm{C}$, while the formation of $\mathrm{CaTiO}_{3}$ is slow and regarded as the rate-limiting step for the FFC process [6].

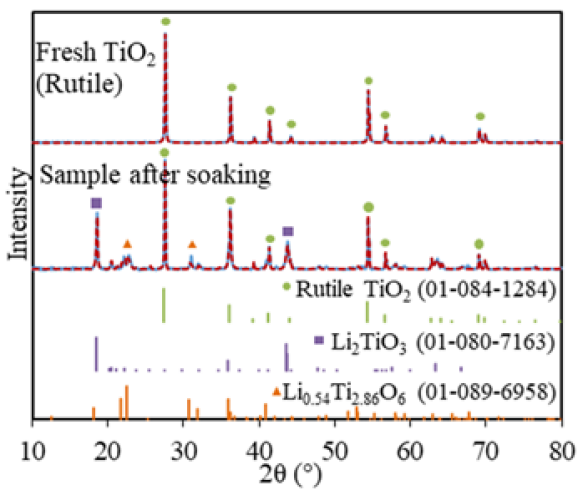

Figure 1. $\mathrm{XRD}$ for fresh $\mathrm{TiO}_{2}$ (rutile) and soaked $\mathrm{TiO}_{2}$ in molten $\mathrm{LiCl}-\mathrm{Li}_{2} \mathrm{O}(1 \mathrm{wt} . \%)$ for $5 \mathrm{~h}$ at $650{ }^{\circ} \mathrm{C}$ (blue solid lines) and Rietveld refinement fittings (red dash lines, with rutile $\mathrm{TiO}_{2}, \mathrm{Li}_{2} \mathrm{TiO}_{3}$, and $\left.\mathrm{Li}_{0.54} \mathrm{Ti}_{2.86} \mathrm{O}_{6}\right)$.

A total of 60.8 wt. $\%$ of $\mathrm{TiO}_{2}$ remained after $5 \mathrm{~h}$ of soaking, which suggested that the diffusion of $\mathrm{Li}^{+}$and $\mathrm{O}^{2-}$ ions through the increasing thickness of the $\mathrm{Li}_{2} \mathrm{TiO}_{3}$ layer had slowed down. The minor $\mathrm{Li}_{0.54} \mathrm{Ti}_{2.86} \mathrm{O}_{6}$ phase also indicated that $\mathrm{Li}_{2} \mathrm{O}$ non-stoichiometrically reacted with the bulk $\mathrm{TiO}_{2}$ phase, possibly because only a very small portion of the $\mathrm{Li}_{2} \mathrm{O}$ reached the fresh $\mathrm{TiO}_{2}$ core due to the slow diffusion through the surface of the $\mathrm{Li}_{2} \mathrm{TiO}_{3}$ layer. This was the first time that the $\mathrm{Li}_{2} \mathrm{TiO}_{3}$ phase was structurally identified for the $\mathrm{TiO}_{2}$ electrolytic reduction in $\mathrm{LiCl}$ salts, which was previously reported only based on the $\mathrm{CV}$ measurement of $\mathrm{TiO}_{2}$ in molten $\mathrm{LiCl}$ (Table 1) [21].

\subsection{Effect of the Reduction Potential on the Electrolytic $\mathrm{TiO}_{2}$ Reduction}

To understand the effect of the reduction potential on the $\mathrm{TiO}_{2}$ electrolytic reduction, various cathodic potentials that were controlled directly using the reference electrode were applied for the $\mathrm{TiO}_{2}$ reduction in $\mathrm{LiCl}-\mathrm{Li}_{2} \mathrm{O}(1 \mathrm{wt} . \%)$ at $650{ }^{\circ} \mathrm{C}$ using $80 \%$ of the theoretical charge. The lithium deposition potential was determined at $-1.75 \mathrm{~V}$ vs. $\mathrm{Ni} / \mathrm{NiO}$, as discussed in a previous study [24]. Figure 2a shows the XRD results with Rietveld refinement analysis for $\mathrm{TiO}_{2}$ electrolytic reductions at cathodic potentials of $-0.2 \mathrm{~V},-0.3 \mathrm{~V}$, and $-0.4 \mathrm{~V}$ vs. $\mathrm{Li} / \mathrm{Li}^{+}$. For all three reduced samples, three phases were identified, including unreacted $\mathrm{TiO}_{2}, \mathrm{Li}_{2} \mathrm{TiO}_{3}$, and $\mathrm{LiTiO}_{2}$ compared with the standard XRDs (Figure 2a). No other reduced 
product or metallic $\mathrm{Ti}$ was detected. Lithium titanates, including $\mathrm{LiTiO}_{2}$ and $\mathrm{Li}_{2} \mathrm{TiO}_{4}$, were reported for the $\mathrm{TiO}_{2}$ electrolytic reduction in $\mathrm{LiCl}$ salts under various conditions, but no $\mathrm{Li}_{2} \mathrm{TiO}_{4}$ was formed in this study [10,19-21]. The quantitative compositional results based on the Rietveld refinement analysis for the three samples reduced at different cathodic potentials were compared with the soaked only $\mathrm{TiO}_{2}$ sample (Figure 2b). Compared with the soaked only $\mathrm{TiO}_{2}$ sample, the unreacted $\mathrm{TiO}_{2}$ content at $-0.2 \mathrm{~V}$ decreased from 60.8 to 14.5 wt.\%, while $\mathrm{Li}_{2} \mathrm{TiO}_{3}$ remained at a similar level around $35.7 \mathrm{wt} . \%$. The partial reduction product $\mathrm{LiTiO}_{2}$ accounted for $49.8 \mathrm{wt} . \%$. These results indicate that $\mathrm{TiO}_{2}$ may have been directly reduced to $\mathrm{LiTiO}_{2}$ by the in-situ-generated $\mathrm{Li}$ metal at $-0.2 \mathrm{~V}$ vs. $\mathrm{Li} / \mathrm{Li}^{+}$ (Equation (7)).

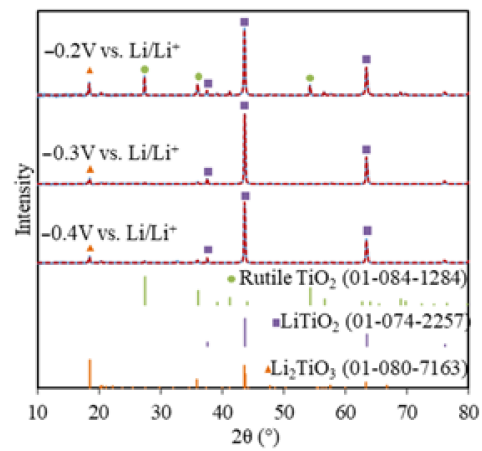

(a)

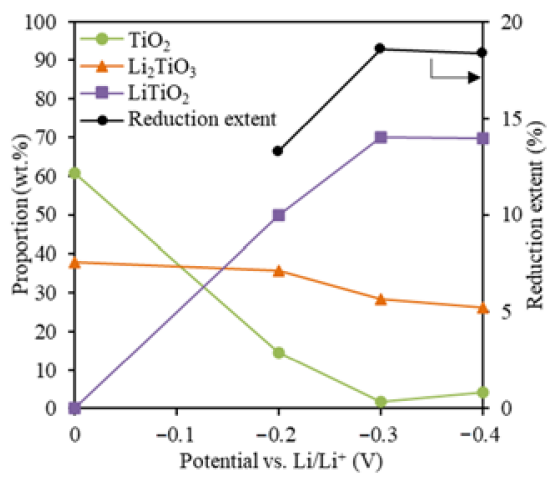

(b)

Figure 2. (a) XRD results (blue solid lines) and Rietveld refinement analysis (red dash lines) of the reduced $\mathrm{TiO}_{2}$ samples at $-0.2 \mathrm{~V},-0.3 \mathrm{~V}$, and $-0.4 \mathrm{~V}$ vs. $\mathrm{Li} / \mathrm{Li}^{+}$with $80 \%$ of the theoretical charge; (b) reduced sample compositions and reduction extents for the $\mathrm{TiO}_{2}$ reductions at $-0.2 \mathrm{~V},-0.3 \mathrm{~V}$, and $-0.4 \mathrm{~V}$ vs. $\mathrm{Li} / \mathrm{Li}^{+}$.

The $\mathrm{TiO}_{2}$ content further decreased to 1.69 wt.\% at $-0.3 \mathrm{~V}$, which lay under the XRD detection limit ( $2 \%$ ). The $\mathrm{Li}_{2} \mathrm{TiO}_{3}$ decreased from 35.7 to $28.3 \%$, while the partial reduction product, $\mathrm{LiTiO}_{2}$, increased from 49.8 to $70.4 \%$. This suggested that both $\mathrm{Li}_{2} \mathrm{TiO}_{3}$ and $\mathrm{TiO}_{2}$ were transformed into $\mathrm{LiTiO}_{2}$ at a higher reduction potential (Equation (8)) and $\mathrm{TiO}_{2}$ was more reducible than $\mathrm{Li}_{2} \mathrm{TiO}_{3}$. The reduction of $\mathrm{Li}_{2} \mathrm{TiO}_{3}$ to $\mathrm{LiTiO}_{2}$ is a reversible reaction $[29,30]$. As the cathodic reduction potential further increased to $-0.4 \mathrm{~V} \mathrm{vs.} \mathrm{Li}^{-} \mathrm{Li}^{+}$, $\mathrm{LiTiO}_{2}$ stayed almost the same, while both $\mathrm{TiO}_{2}$ and $\mathrm{Li}_{2} \mathrm{TiO}_{3}$ only changed slightly within the XRD limit.

Increasing the cathodic reduction potential could promote the $\mathrm{TiO}_{2}$ electrolytic reduction to $\mathrm{LiTiO}_{2}$ to a certain extent, then it started to reduce the current efficiency. A previous study also showed that a high $\mathrm{Li}$ metal concentration impeded the $\mathrm{O}^{2-}$ diffusion and led to a lower reduction extent of $\mathrm{Ti}^{4+}$ [31]. A similar trend was also observed in $\mathrm{CaO} / \mathrm{CaCl}_{2}$ for the $\mathrm{TiO}_{2}$ electrolytic reduction [13]. In this study, the highest achieved $\mathrm{TiO}_{2}$ reduction extent was $18.6 \%$ at $-0.3 \mathrm{~V}$ vs. $\mathrm{Li} / \mathrm{Li}^{+}$using $80 \%$ of the theoretical charge (Figure $2 \mathrm{~b}$ ). The optimal reduction potential for $\mathrm{TiO}_{2}$ reduction in the $\mathrm{LiCl}-\mathrm{Li}_{2} \mathrm{O}(1 \mathrm{wt}$. $\%)$ salt was determined as being $-0.3 \mathrm{~V}$ vs. $\mathrm{Li} / \mathrm{Li}^{+}$.

The $\mathrm{I}(\mathrm{t})$ curves for the $\mathrm{TiO}_{2}$ reduction at all three cathodic reduction potentials showed a similar three-stage pattern, namely, a sharp current peak in the very beginning ( $<20 \mathrm{~min})$, a current decrease, and a steady stage remaining between 0.4 and $0.6 \mathrm{~A}$ (Figure 3 ). The I(t) curves for the $\mathrm{TiO}_{2}$ electrolytic reduction were significantly different from the $\mathrm{I}(\mathrm{t})$ curves for the $\mathrm{NiO}$ and $\mathrm{Cr}_{2} \mathrm{O}_{3}$ reductions, which showed high current plateaus for an extended time until the reduction finished [24,32,33]. The same interval operation mode was used in our previous $\mathrm{NiO}$ study to prevent the excessive accumulation of in-situ-generated $\mathrm{Li}$ metal [24]. The overall current magnitude increased when the reduction potential increased from -0.2 to $-0.4 \mathrm{~V}$ (vs. $\mathrm{Li} / \mathrm{Li}^{+}$), which decreased the experimental time for completing 
$80 \%$ of the theoretical charge for $2 \mathrm{~g} \mathrm{TiO}_{2}$ from 6.5 to $5 \mathrm{~h}$. The $\mathrm{FFC}$ process of $\mathrm{TiO}_{2}$ reduction also produced a similar $\mathrm{I}(\mathrm{t})$ profile $[14,34]$. The first stage of the current increase was attributed to the transformation of the insulator $\mathrm{TiO}_{2}$ to lithium titanate $\mathrm{LiTiO}_{2}$, which has a conductivity of $0.5 \mathrm{~S} \mathrm{~cm}^{-1}$ [35]. According to the three-phase interlines (three PIs) reaction mechanism, the conductive $\mathrm{LiTiO}_{2}$, insulator $\mathrm{TiO}_{2}$, and electrolyte $\mathrm{LiCl}$ can form three PIs [36-38]. As the three PIs expanded from contacting points to a large area, the charge transfer reactions occurring at the three PIs led to an increasing current flow [36]. With more $\mathrm{LiTiO}_{2}$ generated, the interline moved inward to the inside of the $\mathrm{TiO}_{2}$ core. The longer diffusion distance for the three PIs resulted in a sharp current decrease at the beginning of the second stage (Figure 3). When the current continued to decrease at a slower rate, the $\mathrm{Li}_{2} \mathrm{TiO}_{3}$ shell started being reduced to the more conductive $\mathrm{LiTiO}_{2}$ and three new PIs of $\mathrm{LiTiO}_{2} \mid \mathrm{Li}_{2} \mathrm{TiO}_{3}$ I electrolyte were formed. The continuous propagation of the three newly formed three PIs increased the material transfer distance, leading to the continuously decreasing current. The following stage varied little with time (around $0.4 \mathrm{~A}$ ), indicating that either the reaction at the three PIs was limited by the slow diffusion of reactive species or it had reached equilibrium. For the $\mathrm{TiO}_{2}$ electrolytic reduction at $-0.2 \mathrm{~V}$ vs. $\mathrm{Li} / \mathrm{Li}^{+}$, the final product still contained $\mathrm{TiO}_{2}$, while the $\mathrm{Li}_{2} \mathrm{TiO}_{3}$ remained the same, suggesting that the final charge transfer was more relevant with reactions at the three PIs of $\mathrm{LiTiO}_{2} \mid \mathrm{TiO}_{2}$ | electrolyte, where the $\mathrm{O}^{2-}$ diffusion coefficient was estimated as being $1.12 \times 10^{-5} \mathrm{~cm}^{2} \mathrm{~s}^{-1}$. At $-0.3 \mathrm{~V}$ and $-0.4 \mathrm{~V}$ vs. $\mathrm{Li} / \mathrm{Li}^{+}$, the reaction stopped at the reduction of $\mathrm{Li}_{2} \mathrm{TiO}_{3}$ at the three PIs of $\mathrm{LiTiO}_{2}\left|\mathrm{Li}_{2} \mathrm{TiO}_{3}\right|$ electrolyte, where the $\mathrm{O}^{2-}$ diffusion coefficients were estimated as being $1.46 \times 10^{-6} \mathrm{~cm}^{2} \mathrm{~s}^{-1}$ and $1.68 \times 10^{-5} \mathrm{~cm}^{2} \mathrm{~s}^{-1}$, respectively [21,36-38]. The $\mathrm{I}(\mathrm{t})$ curves of the $\mathrm{TiO}_{2}$ reduction were a clear indication of the multistep reaction mechanism, which was limited by the $\mathrm{O}^{2-}$ diffusion from the three PIs to the bulk salts $[13,15]$.

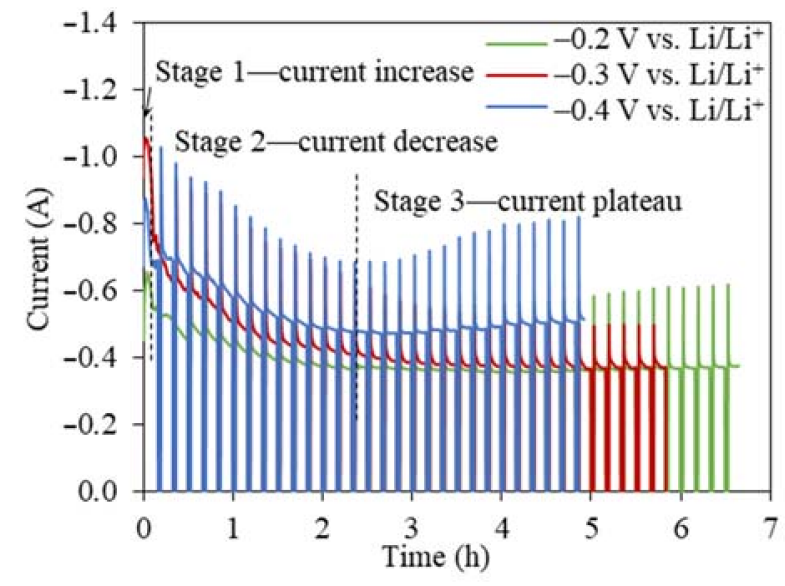

Figure 3. Current-time profiles for the $2 \mathrm{~g} \mathrm{TiO}_{2}$ reductions at cathodic reduction potentials of $-0.2 \mathrm{~V}$, $-0.3 \mathrm{~V}$, and $-0.4 \mathrm{~V}$ vs. $\mathrm{Li} / \mathrm{Li}^{+}$with intervals using $80 \%$ of the theoretical charge.

\subsection{Effect of the Applied Charges on the $\mathrm{TiO}_{2}$ Reductions at $-0.3 \mathrm{~V}$ vs. $\mathrm{Li} / \mathrm{Li}^{+}$}

Using $80 \%$ of the theoretical charge only led to an $18.6 \%$ reduction of $\mathrm{TiO}_{2}$. Thus, further investigation was carried out for $\mathrm{TiO}_{2}$ electrolytic reductions by employing increased charges, namely $130 \%$ and $150 \%$ of the theoretical charge, at the optimal cathodic potential, namely, $-0.3 \mathrm{~V}$ vs. $\mathrm{Li} / \mathrm{Li}^{+}$.

The XRD analysis showed that no metallic Ti was formed for the $\mathrm{TiO}_{2}$ electrolytic reduction when using $130 \%$ and $150 \%$ of the theoretical charge at $-0.3 \mathrm{~V}$ vs. $\mathrm{Li} / \mathrm{Li}^{+}$ (Figure $4 \mathrm{a}$ ). The $\mathrm{TiO}_{2}$ reduction extent increased from 22.3 to $25 \%$ when using $130 \%$ and $150 \%$ of the theoretical charge, respectively; meanwhile, the 13.4 wt. $\%$ of $\mathrm{Li}_{2} \mathrm{TiO}_{3}$ was completely converted to $\mathrm{LiTiO}_{2}$ (Figure $4 \mathrm{~b}$ ). The $28.3 \mathrm{wt}$ \% of $\mathrm{Li}_{2} \mathrm{TiO}_{3}$ remained under $80 \%$ of the theoretical charge and required $70 \%$ more of the theoretical charge to be reduced completely to $\mathrm{LiTiO}_{2}$, suggesting the passivation behavior and stability of $\mathrm{Li}_{2} \mathrm{TiO}_{3}$. 
Furthermore, the formation of $\mathrm{Li}_{2} \mathrm{TiO}_{3}$ in the soaking stage may have slowed down the reduction process in several ways: (1) $\mathrm{Li}_{2} \mathrm{TiO}_{3}$ slowed down the outward diffusion of $\mathrm{O}^{2-}$ and (2) the reduction of $\mathrm{Li}_{2} \mathrm{TiO}_{3}$ was a reversible process, which could be controlled by the $\mathrm{O}^{2-}$ concentration [21,39].

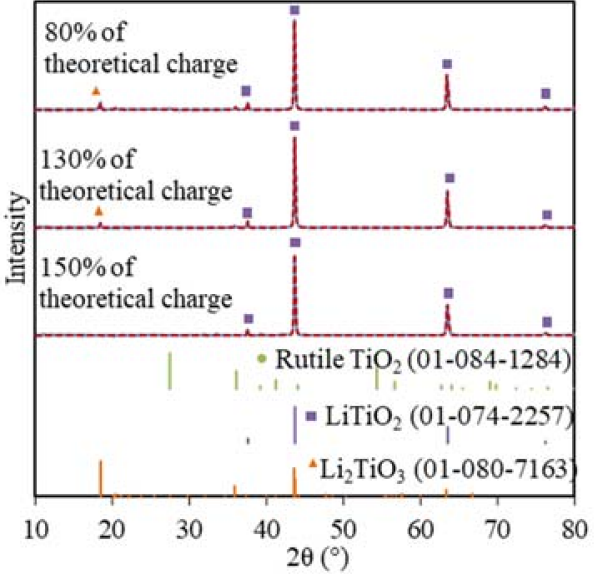

(a)

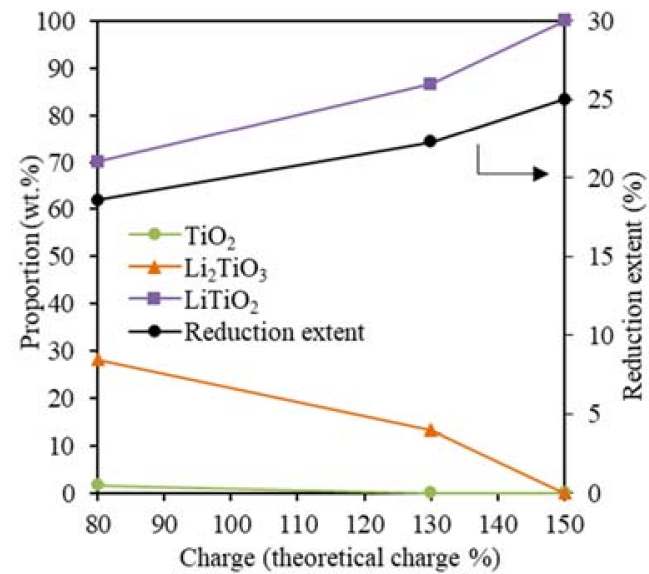

(b)

Figure 4. (a) XRD results (blue solid lines) and Rietveld refinement analysis (red dash lines) of the reduced $\mathrm{TiO}_{2}$ samples at $-0.3 \mathrm{~V}$ vs. $\mathrm{Li} / \mathrm{Li}^{+}$using $80 \%, 130 \%$, and $150 \%$ of the theoretical charge; (b) reduced sample compositions and reduction extents for the $\mathrm{TiO}_{2}$ reductions at $-0.3 \mathrm{~V} \mathrm{vs} . \mathrm{Li} / \mathrm{Li}^{+}$ using $80 \%, 130 \%$, and $150 \%$ of the theoretical charge.

These results show that the $\mathrm{TiO}_{2}$ electrolytic reduction was very refractory, with $\mathrm{LiTiO}_{2}$ being the most reduced product using $150 \%$ of the theoretical charge within $9 \mathrm{~h}$, which was most likely due to the stability of $\mathrm{Li}_{2} \mathrm{TiO}_{3}$ and $\mathrm{LiTiO}_{2}$. The sample geometry played an important role, as the adverse effect of $\mathrm{Li}_{2} \mathrm{TiO}_{3}$ and $\mathrm{LiTiO}_{2}$ on the $\mathrm{TiO}_{2}$ reduction is less pronounced in thin-film and fine powder $\mathrm{TiO}_{2}[10,32]$. The FFC process also shows that the electrolytic reduction of $\mathrm{TiO}_{2}$ in $\mathrm{CaCl}_{2}$ was challenging with a current efficiency that was typically less than $20 \%$, although the much higher temperatures are more kinetically favorable for electrolytic reduction [40]. For the FFC process, the major products obtained within $8 \mathrm{~h}$ were a mixture of $\mathrm{TiO}, \mathrm{CaTiO}_{3}$, and $\mathrm{CaTi}_{2} \mathrm{O}_{4}$, and it took $120 \mathrm{~h}$ to completely reduce $8 \mathrm{~g} \mathrm{TiO}{ }_{2}$ to $\mathrm{Ti}$ in $\mathrm{CaO} / \mathrm{CaCl}_{2}$ at $900{ }^{\circ} \mathrm{C}$ [14]. The electrochemical or chemical formation of various more thermodynamically stable perovskite phases as the intermediate products is one of the main problems contributing to the low current efficiency. The formation of lithium titanates is much easier and faster because the smaller $\mathrm{Li}^{+}$ion leads to faster and deeper intercalation chemical reactions. However, $\mathrm{LiTiO}_{2}$ is more thermodynamically stable than $\mathrm{LiCl}[40]$.

Similar I(t) profiles with a three-stage pattern are observed for $\mathrm{TiO}_{2}$ reductions at $-0.3 \mathrm{~V} \mathrm{vs} . \mathrm{Li} / \mathrm{Li}^{+}$using $130 \%$ and $150 \%$ of the theoretical charge but with an extended time (Figure 5). It took $8.2 \mathrm{~h}$ to apply $150 \%$ of the theoretical charge as the longest experiment among all the $\mathrm{TiO}_{2}$ electrolytic tests in this study, with the highest reduction extent of $25 \%$ of $2 \mathrm{~g} \mathrm{TiO}_{2}$. The steady stage reflects the final charge transfer for the conversion of $\mathrm{Li}_{2} \mathrm{TiO}_{3}$ at the three PIs of $\mathrm{LiTiO}_{2}\left|\mathrm{Li}_{2} \mathrm{TiO}_{3}\right|$ electrolyte [21]. The $\mathrm{O}^{2-}$ diffusion coefficient in the steady state for $130 \%$ and $150 \%$ of the theoretical charge were estimated as being $8.98 \times 10^{-7} \mathrm{~cm}^{2} \mathrm{~s}^{-1}$ and $4.35 \times 10^{-7} \mathrm{~cm}^{2} \mathrm{~s}^{-1}$, which were about one order smaller than that for the steady state when using $80 \%$ of the theoretical charge. The smaller $\mathrm{O}^{2-}$ diffusion coefficients at higher theoretical charges indicates that the conversion of $\mathrm{Li}_{2} \mathrm{TiO}_{3}$ to $\mathrm{LiTiO}_{2}$ was very refractory in the steady stage, which explains the extended reduction process, and hence, the time taken. 


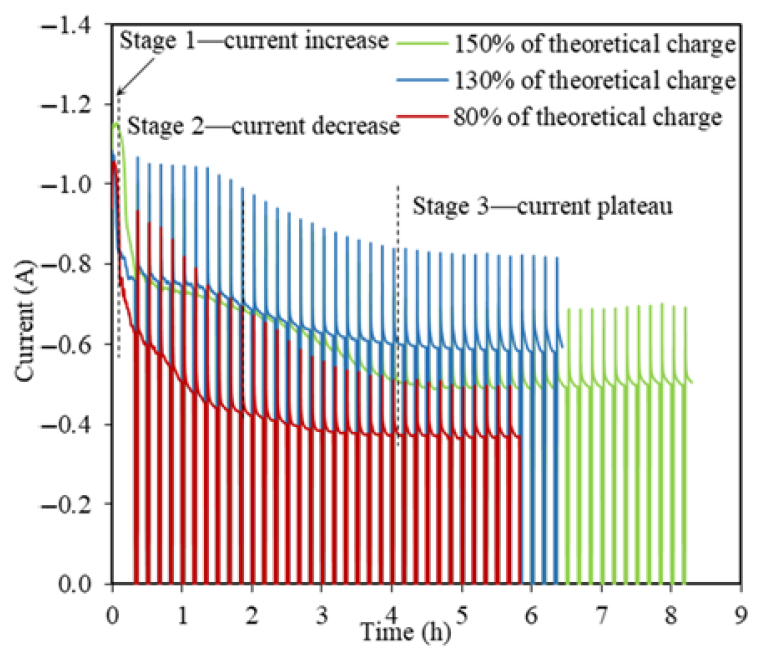

Figure 5. Current-time profiles for the $\mathrm{TiO}_{2}$ reductions at $-0.3 \mathrm{~V}$ vs. $\mathrm{Li} / \mathrm{Li}^{+}$using $80 \%, 130 \%$, and $150 \%$ of the theoretical charge for $2 \mathrm{~g} \mathrm{TiO}_{2}$.

\section{4. $\mathrm{TiO}_{2}$ Reduction Mechanism}

By employing a systematically controlled cathodic potential reduction and charges, reactions (6)-(8) were revealed and discussed for the $\mathrm{TiO}_{2}$ electrolytic reduction process.

The DFT modeling was calculated based on the optimized bulk structures of the relevant compounds, including Li and $\mathrm{Ti}$ (Table S2). Gibbs free energy changes for the possible reactions involved during the $\mathrm{TiO}_{2}$ reduction (Equations (6)-(13)) were calculated (Table 2).

Table 2. Gibbs free energy change and reaction potentials for reactions at $650{ }^{\circ} \mathrm{C}$ using DFT calculations.

\begin{tabular}{|c|c|c|c|}
\hline Reaction & Equation & $\Delta G_{r}\left(\mathrm{~kJ} \cdot \mathrm{mol}^{-1}\right)$ & $\begin{array}{c}\text { Theoretical Potential } \\
\text { (V) }\end{array}$ \\
\hline $\mathrm{TiO}_{2}+\mathrm{Li}_{2} \mathrm{O} \rightarrow \mathrm{Li}_{2} \mathrm{TiO}_{3}$ & (6) & -125.0 & - \\
\hline $\mathrm{Li}+\mathrm{TiO}_{2} \rightarrow \mathrm{LiTiO}_{2}$ & (7) & -113.0 & - \\
\hline $\mathrm{Li}_{2} \mathrm{TiO}_{3}+\mathrm{Li} \leftrightarrow \mathrm{LiTiO}_{2}+\mathrm{Li}_{2} \mathrm{O}$ & (8) & -11.0 & - \\
\hline $\mathrm{LiTiO}_{2}+\mathrm{Li} \rightarrow \mathrm{TiO}+\mathrm{Li}_{2} \mathrm{O}$ & $(9)$ & 0.8 & -0.01 \\
\hline $\mathrm{TiO}+2 \mathrm{Li} \rightarrow \mathrm{Ti}+\mathrm{Li}_{2} \mathrm{O}$ & (10) & -22.3 & - \\
\hline $\mathrm{TiO} \rightarrow \mathrm{Ti}+1 / 2 \mathrm{O}_{2}$ & (11) & 227.0 & -1.18 \\
\hline $\mathrm{Li}_{2} \mathrm{TiO}_{3} \rightarrow \mathrm{LiTiO}_{2}+\frac{1}{2} \mathrm{Li}_{2} \mathrm{O}+\frac{1}{4} \mathrm{O}_{2}$ & $(12)$ & 222.0 & -2.30 \\
\hline $\mathrm{LiTiO}_{2} \rightarrow \mathrm{TiO}+\frac{1}{2} \mathrm{Li}_{2} \mathrm{O}+\frac{1}{4} \mathrm{O}_{2}$ & (13) & 212.0 & -2.20 \\
\hline
\end{tabular}

The negative Gibbs free energy $\Delta G_{650}{ }^{\circ} \mathrm{C}=-125 \mathrm{~kJ} \mathrm{~mol}^{-1}$ for the insertion reaction of $\mathrm{Li}_{2} \mathrm{O}$ to $\mathrm{TiO}_{2}$ indicates that the formation of $\mathrm{Li}_{2} \mathrm{TiO}_{3}$ was spontaneous at $650{ }^{\circ} \mathrm{C}$ (Equation (6)), which is consistent with the $\mathrm{TiO}_{2}$ soaking only testing result. The $\Delta G_{650}{ }^{\circ} \mathrm{C}$ for the $\mathrm{TiO}_{2}$ reduction with $\mathrm{Li}$ metal was more negative than that for the reduction of $\mathrm{Li}_{2} \mathrm{TiO}_{3}$ with $\mathrm{Li}$ metal, suggesting that the reduction of $\mathrm{TiO}_{2}$ with $\mathrm{Li}$ was more favorable than $\mathrm{Li}_{2} \mathrm{TiO}_{3}$ (Equation (7) vs. Equation (8)). The remaining core of the $\mathrm{TiO}_{2}$ was most likely reduced to $\mathrm{LiTiO}_{2}$ before the $\mathrm{Li}_{2} \mathrm{TiO}_{3}$ shell reduction, which could be slowed down by the $\mathrm{Li}_{2} \mathrm{TiO}_{3}$ passivation layer. The unit cell volume of $\mathrm{Li}_{2} \mathrm{TiO}_{3}$ was three times as much as the one for $\mathrm{TiO}_{2}$, which not only reduced the pore volume for the transport of $\mathrm{O}^{2-}$ ions but was more thermodynamically stable (Figure 6) $[6,40]$. The reduction of $\mathrm{Li}_{2} \mathrm{TiO}_{3}$ by the $\mathrm{Li}$ metal generated $\mathrm{Li}_{2} \mathrm{O}$ (Equation (8)), which needed to diffuse through the $\mathrm{LiTiO}_{2}$ layer to the bulk molten salts. The slow diffusion of $\mathrm{O}^{2-}$ through the $\mathrm{LiTiO}_{2}$ layer led to the accumulation of trapped $\mathrm{Li}_{2} \mathrm{O}$ in the solid particle, which limited the reversible reduction of $\mathrm{Li}_{2} \mathrm{TiO}_{3}$. The further reduction of $\mathrm{LiTiO}_{2}$ by the Li metal also generated $\mathrm{Li}_{2} \mathrm{O}$ (Equation (9), $\Delta G_{r}=0.8 \mathrm{~kJ} \mathrm{~mol}^{-1}$ ). The direct electrolytic reductions of $\mathrm{Li}_{2} \mathrm{TiO}_{3}$ and $\mathrm{LiTiO}_{2}$ were alterna- 
tive pathways for the titanium dioxides' reduction at underpotentials (Equations (12) and (13)), for which the Gibbs free energies were much higher. Both reduction pathways of $\mathrm{LiTiO}_{2}$ were most likely halted due to the high local $\mathrm{Li}_{2} \mathrm{O}$ concentration (Equations (9) and (13)), which became the key limiting step for further reduction and caused the extended time. The DFT analysis was consistent with the experimental $\mathrm{TiO}_{2}$ electrolytic reduction results obtained in this study showing that the $\mathrm{LiTiO}_{2}$ was the most reduced product achieved, even when using $150 \%$ of the theoretical charge. The passivation and refractory behaviors of $\mathrm{LiTiO}_{3}$ were witnessed for the electrolytic reduction of $\mathrm{TiO}_{2}$ in the $\mathrm{LiCl}$ molten salts using underpotentials before the formation of the Li metal $[19,40]$.

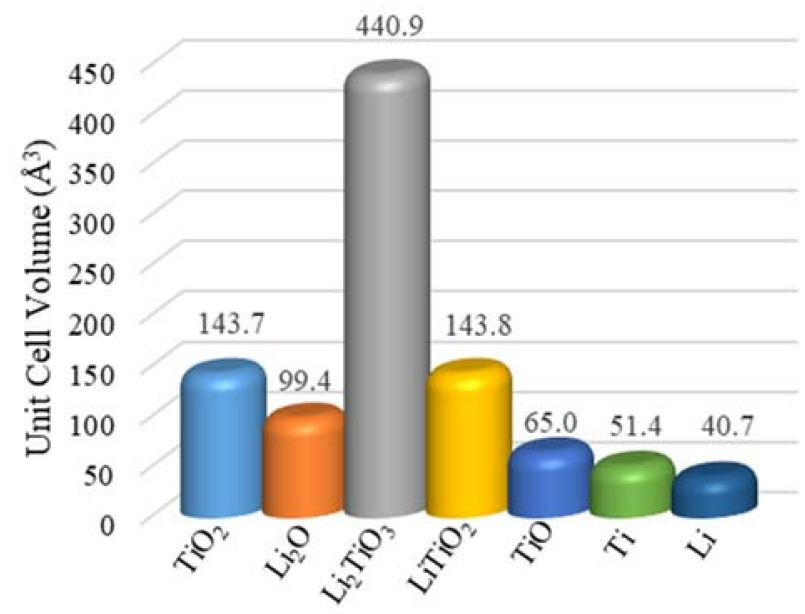

Figure 6. Unit cell volumes for the related chemicals during the $\mathrm{TiO}_{2}$ electrolytic reduction in the molten $\mathrm{LiCl}-\mathrm{Li}_{2} \mathrm{O}(1 \mathrm{wt} . \%)$ at $650{ }^{\circ} \mathrm{C}$.

By combining the experimental and DFT results, a three-step reaction mechanism for the $\mathrm{TiO}_{2}$ electrolytic reduction at overpotentials in the $\mathrm{LiCl}-\mathrm{Li}_{2} \mathrm{O}(1 \mathrm{wt} . \%)$ salt at $650{ }^{\circ} \mathrm{C}$ was proposed for this study:

Step 1: $\mathrm{Li}_{2} \mathrm{O}+\mathrm{TiO}_{2} \rightarrow \mathrm{Li}_{2} \mathrm{TiO}_{3}$;

Step 2: $\mathrm{TiO}_{2}+\mathrm{Li} \rightarrow \mathrm{LiTiO}_{2}$;

Step 3: $\mathrm{Li}_{2} \mathrm{TiO}_{3}+\mathrm{Li} \leftrightarrow \mathrm{LiTiO}_{2}+\mathrm{Li}_{2} \mathrm{O}$ (reversible).

As illustrated in Figure 7, the soaking process followed a shrinking core mechanism, where the insertion of $\mathrm{Li}_{2} \mathrm{O}$ and $\mathrm{TiO}_{2}$ formed a stoichiometric $\mathrm{Li}_{2} \mathrm{TiO}_{3}$ layer on the external surface of the $\mathrm{TiO}_{2}$ particles [16]. The $\mathrm{Li}_{2} \mathrm{TiO}_{3}$ layer became thicker and slowed down the $\mathrm{O}^{2-}$ diffusion, leading to unstoichiometric $\mathrm{Li}_{0.54} \mathrm{Ti}_{2.86} \mathrm{O}_{6}$ formation with the unreacted $\mathrm{TiO}_{2}$ core.

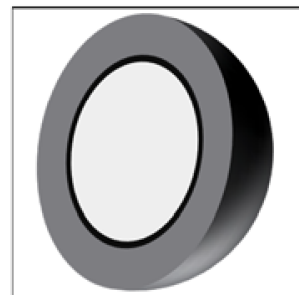

(a)

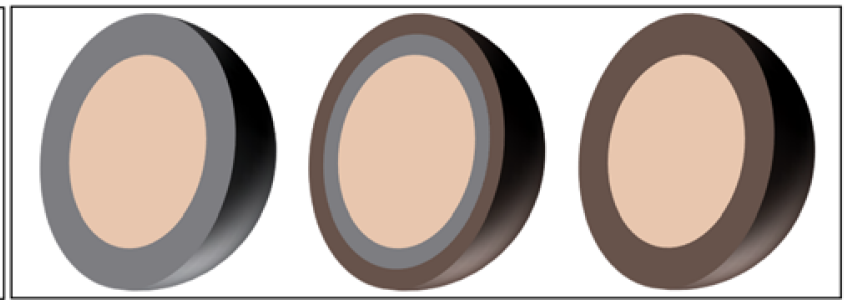

(b)
$\bigcirc \mathrm{TiO}_{2}$
$\mathrm{Li}_{0.54} \mathrm{Ti}_{2.86} \mathrm{O}_{6}$
$\mathrm{Li}_{2} \mathrm{TiO}_{3}$
$\mathrm{LiTiO}_{2}$
$\mathrm{LiTiO}_{2}+\mathrm{Li}_{2} \mathrm{O}$

Figure 7. Shrinking core model for (a) the $\mathrm{TiO}_{2}$ soaking process and (b) for the electrolytic reduction of the $\mathrm{TiO}_{2}$ process with a passivation layer.

The $\mathrm{Li}_{2} \mathrm{TiO}_{3} \mid \mathrm{TiO}_{2}$ | electrolyte interline initially formed on the surface of the oxide particle and gradually moved to the interior of the particle. 
In the second step, the $\mathrm{Li}$ metal diffused through the $\mathrm{Li}_{2} \mathrm{TiO}_{3}$ and reduced the $\mathrm{TiO}_{2}$ core directly into $\mathrm{LiTiO}_{2}$. The three PIs of $\mathrm{LiTiO}_{2}\left|\mathrm{TiO}_{2}\right|$ electrolyte were formed. The lithium metal continuously moved to the center of the $\mathrm{TiO}_{2}$ core until the core was fully converted to $\mathrm{LiTiO}_{2}$. This step was controlled by the $\mathrm{Li}$ diffusion through the $\mathrm{Li}_{2} \mathrm{TiO}_{3}$ and newly formed $\mathrm{LiTiO}_{2}$ layer. The second reaction also followed a shrinking-core model. When the $\mathrm{TiO}_{2}$ was completely reduced to $\mathrm{LiTiO}_{2}$, the $\mathrm{Li}_{2} \mathrm{TiO}_{3}$ shell started to be reduced to a mixture of $\mathrm{LiTiO}_{2}$ and $\mathrm{Li}_{2} \mathrm{O}$, which was different from the inner $\mathrm{LiTiO}_{2}$ core. The reaction occurred at the external layer of $\mathrm{Li}_{2} \mathrm{TiO}_{3}$ and formed a new three PIs of $\mathrm{Li}_{2} \mathrm{O}+\mathrm{LiTiO} \mathrm{I}_{2}\left|\mathrm{Li}_{2} \mathrm{TiO}_{3}\right|$ electrolyte. It stopped when the interline approached the $\mathrm{LiTiO}_{2}$ core. In the $\mathrm{I}(\mathrm{t})$ curves, the second current reduction session took a long time and the data presented in Figure 4a shows that the conversion of $\mathrm{Li}_{2} \mathrm{TiO}_{3}$ to $\mathrm{LiTiO}_{2}$ was not completed until $150 \%$ of the theoretical charge was applied. This indicates that $\mathrm{Li}_{2} \mathrm{TiO}_{3}$ was stable and the reduction of $\mathrm{Li}_{2} \mathrm{TiO}_{3}$ was refractory. Therefore, the third step was the rate-limiting step in the $\mathrm{TiO}_{2}$ reduction in the molten $\mathrm{LiCl}-\mathrm{Li}_{2} \mathrm{O}$.

Important physical variables determine the electrolytic reduction process, including the diffusion coefficient of oxygen in various phases, the applied current density, the radius of the grains, and the density of the phase [16]. In this study, the most reduced product obtained for the electrolytic reduction of $\mathrm{TiO}_{2}$ was $\mathrm{LiTiO}_{2}$ with $150 \%$ of the theoretical charge in $8.2 \mathrm{~h}$. Previous studies on $\mathrm{TiO}_{2}$ electrolytic reduction using the pellet form (thickness $\approx 0.2 \mathrm{~cm}$ ) at cell potentials of $1.8 \mathrm{~V}$ and $3.2 \mathrm{~V}$ also only achieved $\mathrm{LiTi}_{2} \mathrm{O}_{4}$ and $\mathrm{LiTiO}_{2}$ within several hours [19]. In contrast, the complete reduction of the $\mathrm{TiO}_{2}$ powder in $\mathrm{LiCl}$ was achieved with both $\mathrm{CV}$ techniques and potentioamperometry $[10,21] . \mathrm{Li}_{2} \mathrm{O}$ accumulation within the pellet may alternate the conductivity of the mixtures and slow down the direct electrolytic reduction of $\mathrm{Li}_{2} \mathrm{TiO}_{3}$ and $\mathrm{LiTiO}_{2}$, which was observed for other metal oxide reductions [27].

The key to improving the $\mathrm{TiO}_{2}$ reduction in $\mathrm{LiCl}-\mathrm{Li}_{2} \mathrm{O}$ molten salts is to reduce the $\mathrm{Li}_{2} \mathrm{O}$ local concentration and promote the diffusion of $\mathrm{O}^{2-}$ out of the solid phase. Strategies to achieve this include lowering the $\mathrm{Li}_{2} \mathrm{O}$ concentration in the molten salts, reducing the pellet size, and applying sonication or mechanical stirring to accelerate the $\mathrm{O}^{2-}$ diffusion [41]. Furthermore, as the Ti species valence reduced to 0 step by step according to the DFT analysis for the multistep reduction, the $\Delta G$ changed from negative to positive. This indicates that the stepwise reduction of $\mathrm{TiO}_{2}$ with the in-situ-generated $\mathrm{Li}$ metal reached thermodynamic equilibrium and gradually became more refractory, although the overall $\Delta G$ for the $\mathrm{TiO}_{2}$ reduction was negative and the reaction was spontaneous. Another promising way to improve the $\mathrm{TiO}_{2}$ electrolytic reduction in $\mathrm{LiCl}$ is to avoid the intermediate steps, such as removing the soaking step or decrease it to a reasonably short time.

\section{Conclusions}

Electrolytic $\mathrm{TiO}_{2}$ reduction in $\mathrm{LiCl}-\mathrm{Li}_{2} \mathrm{O}$ salts at $650{ }^{\circ} \mathrm{C}$ was examined in terms of a soaking only test, the effect of a reduction potential, and the effect of applied charges. The soaking without electrolysis showed the spontaneous formation of $\mathrm{Li}_{2} \mathrm{TiO}_{3}$, which is a unique intermediate for $\mathrm{TiO}_{2}$ electrolytic reduction. The increasing reduction potential promoted $\mathrm{TiO}_{2}$ reduction only to a certain extent. The optimal cathodic reduction potential was determined as being $-0.3 \mathrm{~V}$ vs. $\mathrm{Li} / \mathrm{Li}^{+}$. The highest charge, i.e., $150 \%$ of the theoretical charge, was applied for $8.2 \mathrm{~h}$ and caused the partial reduction of $\mathrm{TiO}_{2}$ through to the full conversion of $\mathrm{LiTiO}_{2}$, which was the most reduced product obtained in this study. Accordingly, the highest reduction extent was $25 \%$.

Combined with the DFT modeling, the electrolytic reduction of $\mathrm{TiO}_{2}$ in molten $\mathrm{LiCl}-$ $\mathrm{Li}_{2} \mathrm{O}$ was proposed to follow a multistep reaction mechanism. The external surface of the $\mathrm{TiO}_{2}$ particles was converted to $\mathrm{Li}_{2} \mathrm{TiO}_{3}$ via the chemical insertion of $\mathrm{Li}_{2} \mathrm{O}$ during the soaking stage. Then, the $\mathrm{TiO}_{2}$ core was partially reduced to $\mathrm{LiTiO}_{2}$ before $\mathrm{Li}_{2} \mathrm{TiO}_{3}$ was electrolytically reduced to $\mathrm{LiTiO}_{2}$. The reduction of $\mathrm{Li}_{2} \mathrm{TiO}_{3}$ was reversible and led to the formation of $\mathrm{Li}_{2} \mathrm{O}$. Due to the accumulation of $\mathrm{Li}_{2} \mathrm{O}$ at the three PIs, the reduction of 
$\mathrm{Li}_{2} \mathrm{TiO}_{3}$ to $\mathrm{LiTiO}_{2}$ was very slow and the rate-limiting step. Further reduction of $\mathrm{LiTiO}_{2}$ was paused as more $\mathrm{Li}_{2} \mathrm{O}$ was generated and accumulated.

Based on the understanding of the $\mathrm{TiO}_{2}$ electrolytic reduction mechanism in molten $\mathrm{LiCl}-\mathrm{Li}_{2} \mathrm{O}$, the key to increasing the efficiency of electrolytic $\mathrm{TiO}_{2}$ reduction is to reduce the $\mathrm{O}^{2-}$ ions concentration at the three PIs. Strategies to achieve this include promoting the $\mathrm{O}^{2-}$ diffusion at the three PIs, using smaller $\mathrm{TiO}_{2}$ particles or powder, using a lower concentration of $\mathrm{Li}_{2} \mathrm{O}$ for the bulk salts, and reducing the soaking time to avoid the excessive formation of $\mathrm{Li}_{2} \mathrm{TiO}_{3}$.

Supplementary Materials: The followings are available online at https:/ /www.mdpi.com/article/ 10.3390/electrochem2020016/s1. Figure S1: Optimized bulk crystal structures for the Li system, $\mathrm{TiO}_{2}, \mathrm{TiO}$, and Ti. Table S1: Rietveld refinement results for the soaked and reduced products. Table S2: Optimized bulk lattice parameters. Table S3: Equation of state, equilibrium volumes (V_0) determined from corresponding BM4 EOS, bulk moduli, and electronic potentials for the materials modeled from DFT.

Author Contributions: Conceptualization, S.L. and H.Z.; methodology, S.L. and H.Z.; software, B.L.; validation, M.S., B.L., S.L. and H.Z.; formal analysis, M.S. and H.Z.; resources, S.L. and B.L.; data curation, M.S.; writing — original draft preparation, M.S.; writing—review and editing, H.Z.; visualization, B.L.; project administration, S.L. and H.Z.; funding acquisition, S.L. All authors have read and agreed to the published version of the manuscript.

Funding: This research was supported through the INL Laboratory Directed Research and Development (LDRD) Program under DOE Idaho Operations Office Contract DE-AC07-05ID14517.

Institutional Review Board Statement: Not applicable.

Informed Consent Statement: Not applicable.

Data Availability Statement: Not applicable.

Acknowledgments: The authors would like to thank the staff at the Center for Advanced Energy Studies for their assistance and the use of their facilities.

Conflicts of Interest: The authors declare no conflict of interest.

\section{References}

1. Shenouda, A.Y.; Murali, K.R. Electrochemical Properties of Doped Lithium Titanate Compounds and Their Performance in Lithium Rechargeable Batteries. J. Power Sources 2008, 176, 332-339. [CrossRef]

2. Nemeth, T.; Schröer, P.; Kuipers, M.; Sauer, D.U. Lithium Titanate Oxide Battery Cells for High-Power Automotive Applications -Electro-Thermal Properties, Aging Behavior and Cost Considerations. J. Energy Storage 2020, 31, 101656. [CrossRef]

3. Cui, C.; Hu, B.; Zhao, L.; Liu, S. Titanium Alloy Production Technology, Market Prospects and Industry Development. Mater. Des. 2011, 32, 1684-1691. [CrossRef]

4. Smith, P.R.; Froes, F.H. Developments in Titanium Metal Matrix Composites. JOM 1984, 36, 19-26. [CrossRef]

5. Chen, G.Z.; Fray, D.J.; Farthing, T.W. Direct Electrochemical Reduction of Titanium Dioxide to Titanium in Molten Calcium Chloride. Nature 2000, 407, 361-364. [CrossRef] [PubMed]

6. Jiang, K.; Hu, X.; Ma, M.; Wang, D.; Qiu, G.; Jin, X.; Chen, G.Z. "Perovskitization”-Assisted Electrochemical Reduction of Solid $\mathrm{TiO}_{2}$ in Molten $\mathrm{CaCl}_{2}$. Angew. Chem. Int. Ed. 2006, 45, 428-432. [CrossRef] [PubMed]

7. Suzuki, R.O. Calciothermic Reduction of $\mathrm{TiO}_{2}$ and in Situ Electrolysis of $\mathrm{CaO}$ in the $\mathrm{Molten} \mathrm{CaCl}_{2}$. J. Phys. Chem. Solids 2005, 66, 461-465. [CrossRef]

8. Suzuki, R.O. Direct Reduction Processes for Titanium Oxide in Molten Salt. JOM 2007, 59, 68-71. [CrossRef]

9. Ono, K.; Suzuki, R.O. A New Concept for Producing Ti Sponge: Calciothermic Reduction. JOM 2002, 54, 59-61. [CrossRef]

10. Shin, H.-S.; Hur, J.-M.; Jeong, S.M.; Jung, K.Y. Direct Electrochemical Reduction of Titanium Dioxide in Molten Lithium Chloride. J. Ind. Eng. Chem. 2012, 18, 438-442. [CrossRef]

11. Herrmann, S.D.; Li, S.X. Separation and Recovery of Uranium Metal from Spent Light Water Reactor Fuel Via Electrolytic Reduction and Electrorefining. Nucl. Technol. 2010, 171, 247-265. [CrossRef]

12. Jeong, S.M.; Jung, J.-Y.; Seo, C.-S.; Park, S.-W. Characteristics of an Electrochemical Reduction of Ta2O5 for the Preparation of Metallic Tantalum in a LiCl- $\mathrm{Li}_{2} \mathrm{O}$ Molten Salt. J. Alloy. Compd. 2007, 440, 210-215. [CrossRef]

13. Schwandt, C.; Alexander, D.T.L.; Fray, D.J. The Electro-Deoxidation of Porous Titanium Dioxide Precursors in Molten Calcium Chloride under Cathodic Potential Control. Electrochim. Acta 2009, 54, 3819-3829. [CrossRef] 
14. Schwandt, C.; Fray, D.J. Determination of the Kinetic Pathway in the Electrochemical Reduction of Titanium Dioxide in Molten Calcium Chloride. Electrochim. Acta 2005, 51, 66-76. [CrossRef]

15. Alexander, D.T.L.; Schwandt, C.; Fray, D.J. The Electro-Deoxidation of Dense Titanium Dioxide Precursors in Molten Calcium Chloride Giving a New Reaction Pathway. Electrochim. Acta 2011, 56, 3286-3295. [CrossRef]

16. Kar, P.; Evans, J.W. A Shrinking Core Model for the Electro-Deoxidation of Metal Oxides in Molten Halide Salts. Electrochim. Acta 2008, 53, 5260-5265. [CrossRef]

17. Suzuki, R.O.; Ono, K.; Teranuma, K. Calciothermic Reduction of Titanium Oxide and In-Situ Electrolysis in $\mathrm{Molten}^{\mathrm{CaCl}} 2$. Metall. Mater. Trans. B 2003, 34, 287-295. [CrossRef]

18. Kikuchi, T.; Yoshida, M.; Matsuura, S.; Natsui, S.; Tsuji, E.; Habazaki, H.; Suzuki, R.O. Rapid Reduction of Titanium Dioxide Nano-Particles by Reduction with a Calcium Reductant. J. Phys. Chem. Solids 2014, 75, 1041-1048. [CrossRef]

19. Jiang, K.; Hu, X.; Sun, H.; Wang, D.; Jin, X.; Ren, Y.; Chen, G.Z. Electrochemical Synthesis of $\mathrm{LiTiO}_{2}$ and $\mathrm{LiTi}_{2} \mathrm{O}_{4}$ in Molten LiCl. Chem. Mater. 2004, 16, 4324-4329. [CrossRef]

20. Jin-Mok, H.; Su-Chul, L.; Sang-Mun, J.; Chung-Seok, S. Electrochemical Reduction of $\mathrm{TiO}_{2}$ in Molten LiCl-Li $2 \mathrm{O}$. Chem. Lett. 2007, 36, 1028-1029. [CrossRef]

21. Dring, K. Direct Electrochemical Reduction of Titanium Dioxide in Molten Salts. Key Eng. Mater. 2010, 436, 27-34. [CrossRef]

22. Bhagat, R.; Dye, D.; Raghunathan, S.L.; Talling, R.J.; Inman, D.; Jackson, B.K.; Rao, K.K.; Dashwood, R.J. In Situ Synchrotron Diffraction of the Electrochemical Reduction Pathway of $\mathrm{TiO}_{2}$. Acta Mater. 2010, 58, 5057-5062. [CrossRef]

23. Alexander, D.T.L.; Schwandt, C.; Fray, D.J. Microstructural Kinetics of Phase Transformations during Electrochemical Reduction of Titanium Dioxide in Molten Calcium Chloride. Acta Mater. 2006, 54, 2933-2944. [CrossRef]

24. Shi, M.; Li, S.; Zhao, H. High Current Efficiency of NiO Electro-Reduction in Molten Salt. J. Electrochem. Soc. 2018, 165, E768-E772. [CrossRef]

25. Kresse, G.; Hafner, J. Ab Initio Molecular Dynamics for Liquid Metals. Phys. Rev. B 1993, 47, 558-561. [CrossRef]

26. Kresse, G.; Joubert, D. From Ultrasoft Pseudopotentials to the Projector Augmented-Wave Method. Phys. Rev. B 1999, 59, 1758-1775. [CrossRef]

27. Burak, A.J.; Simpson, M.F. Electrochemical Measurement of $\mathrm{Li}_{2} \mathrm{O}$ in Molten LiCl Salt. ECS Trans. 2016, 75, 55-61. [CrossRef]

28. Joseph, T.B.; Sanil, N.; Mohandas, K.S.; Nagarajan, K. A Study of Graphite as Anode in the Electro-Deoxidation of Solid $\mathrm{UO}_{2}$ in LiCl-Li 2 O Melt. J. Electrochem. Soc. 2015, 162, E51-E58. [CrossRef]

29. van de Krol, R.; Goossens, A.; Schoonman, J. Spatial Extent of Lithium Intercalation in Anatase TiO 2. J. Phys. Chem. B 1999, 103, 7151-7159. [CrossRef]

30. Macklin, W.J.; Neat, R.J. Performance of Titanium Dioxide-Based Cathodes in a Lithium Polymer Electrolyte Cell. Solid State Ion. 1992, 53-56, 694-700. [CrossRef]

31. Merwin, A. Material Interactions with Molten LiCl-Li 2 O-Li. Ph.D. Thesis, University of Nevada, Reno, NV, USA, 2016.

32. Chen, G.Z.; Gordo, E.; Fray, D.J. Direct Electrolytic Preparation of Chromium Powder. Metall. Mater. Trans. B 2004, $35,223-233$. [CrossRef]

33. Gordo, E.; Chen, G.Z.; Fray, D.J. Toward Optimisation of Electrolytic Reduction of Solid Chromium Oxide to Chromium Powder in Molten Chloride Salts. Electrochim. Acta 2004, 49, 2195-2208. [CrossRef]

34. Fray, D.J.; Chen, G.Z. Reduction of Titanium and Other Metal Oxides Using Electrodeoxidation. Mater. Sci. Technol. 2004, 20, 295-300. [CrossRef]

35. Robin, M.B.; Day, P. Mixed Valence Chemistry-A Survey and Classification. In Advances in Inorganic Chemistry and Radiochemistry; Emeléus, H.J., Sharpe, A.G., Eds.; Academic Press: Cambridge, UK, 1968; Volume 10, pp. 247-422. ISBN 0065-2792.

36. Xiao, W.; Jin, X.; Deng, Y.; Wang, D.; Hu, X.; Chen, G.Z. Electrochemically Driven Three-Phase Interlines into Insulator Compounds: Electroreduction of Solid $\mathrm{SiO}_{2}$ in Molten $\mathrm{CaCl}_{2}$. ChemPhysChem 2006, 7, 1750-1758. [CrossRef]

37. Deng, Y.; Wang, D.; Xiao, W.; Jin, X.; Hu, X.; Chen, G.Z. Electrochemistry at Conductor/Insulator/Electrolyte Three-Phase Interlines: A Thin Layer Model. J. Phys. Chem. B 2005, 109, 14043-14051. [CrossRef]

38. Wu, T.; Jin, X.; Xiao, W.; Hu, X.; Wang, D.; Chen, G.Z. Thin Pellets: Fast Electrochemical Preparation of Capacitor Tantalum Powders. Chem. Mater. 2007, 19, 153-160. [CrossRef]

39. Ohzuku, T. Zero-Strain Insertion Material of $\mathrm{Li}_{1 / 3} \mathrm{Ti}_{5 / 3} \mathrm{O}_{4}$ for Rechargeable Lithium Cells. J. Electrochem. Soc. 1995, $142,1431$. [CrossRef]

40. Qiu, G.; Jiang, K.; Ma, M.; Wang, D.; Jin, X.; Chen, G.Z. Roles of Cationic and Elemental Calcium in the Electro-Reduction of Solid Metal Oxides in Molten Calcium Chloride. Z. Nat. A 2014, 62, 292. [CrossRef]

41. Mandroyan, A.; Mourad-Mahmoud, M.; Doche, M.-L.; Hihn, J.-Y. Effects of Ultrasound and Temperature on Copper Electro Reduction in Deep Eutectic Solvents (DES). Ultrason. Sonochem. 2014, 21, 2010-2019. [CrossRef] [PubMed] 